\title{
The Relationship Between Lectin Compounds and Immunomodulatory Activities of Protein Extracted From Plants
}

\author{
Abdeljlil Daoudi $^{1}$, Essam Abdel-Satter ${ }^{2} \&$ Lotfi Aarab ${ }^{1}$ \\ ${ }^{1}$ Laboratory of Bioactive Molecules, Unit of Immunology and Pharmacology, Faculty of Science \& Technology, \\ Fez, Morocco \\ ${ }^{2}$ Deptartment of Pharmacognosy, Faculty of Pharmacy, Cairo University, Cairo, Egypt \\ Correspondence: Abdeljlil Daoudi, Laboratory of Bioactive Molecules, Unit of Immunology and Pharmacology, \\ Faculty of Science \& Technology, Fez, Morocco. Tel: 212-676-470-677. E-mail: daoudiabdeljlil@yahoo.fr
}

Received: July 2, 2013 Accepted: November 20, 2013 Online Published: November 27, 2013

doi:10.5539/jps.v3n1p56

URL: http://dx.doi.org/10.5539/jps.v3n1p56

\begin{abstract}
Lectins are carbohydrate-binding proteins of non-immune origin. They are essential components of plant active substances used by the plant in its system of defense and symbiotic interactions. It is expected that there is a relation between immunomodulatory activity of the protein extract and its content of lectin. In this study, we are aiming to explore the relation between the lectin content and the immunomodulatory activity using the erythroagglutination test of a group of immunomodulating protein plant extracts previously evaluated. The result shows that there is no relationship between the immunostimulatory activity and the presence or absence of lectins; lectins are not always immunostimulatory compounds; and they can also depressed immune activity. The erythro-agglutination is found qualitatively and quantitatively depending on the nature of lectin and its concentration in the protein extracted. Therefore, the lectin immunostimulatory effects found can also be used with an adjuvant effect in vaccine development; while, the lectin immunoinhibitory effects can be used in the cancer therapy.
\end{abstract}

Keywords: immunomodulatory, lectins, erythro-agglutination, Concanavalin-A

\section{Introduction}

Plant resources constantly providing and enhancing the health care system by providing new natural bioactive substances such as lectins. This lectin are defined as protein or glycoprotein non-immune origin with a carbohydrate through at least two binding sites, which agglutinate cells and precipitating polysaccharides, glycoproteins or glycolipids (Goldstein et al., 1980). The presence of lectins is mainly detected throught a hemagglutinating assay (Frost et al., 1975; Qu et al., 1986; Kennedy et al., 1995).

Regarding to the biological role of lectins, it appears that they are made to act in the inside and in the outside of the plants, as a tool or reaction mediators including agricultural (plant defense against the pathogens) (Peumans \& Van Damme, 1995), immunology (antimicrobial and immunomodulatory) ( Ryder et al., 1992; Wang et al., 1996; Rubinstein et al., 2004; de Melo et al., 2011), serology (identification blood cell banks) (Boyd \& Shapleigh, 1954; Khan et al., 2007; Meite et al., 2008), cancer (histochemical markers such as cancer and toxicity of cancer cell lines) (Guillot et al., 2004; Liu et al., 2010; Zwierzina et al., 2011), biochemistry (characterization, isolation and purification) (Hirabayashi, 2004; Peumans \& Van Damme, 1998), and other biological field (reserve role, hormonal mimicry and enzymatique mimicry) (Meite et al., 2006).

The immunological activity of lectin plants has been evaluated in several assays, including phytohemagglutinin from Phaseolus vulgaris L (PHA), which is known for its ability to stimulate lymphocytes (de Oliveira et al., 2011). Other studies demonstrated the lectin from Viscum album L, which is isolated as immunomodulatory activity of macrophage-mediated immune responses and enhanced aussi the term of various cytokines (IL-3, IL-23 and TNF-a) (Lee et al., 2007). Other lectin activates the monocytes and the macrophages (Melo et al., 2010) and ROS production by spleen cells (Ringner et al., 1994), also, lectins have been exploited to characterize and qualify serum glycoprotein's in the control of rheumatoid arthritis and as an important immunosuppressive in bone marrow transplantation (Kennedy et al., 1995).

Following of the importance immunomodulatory of lectins manifested by multiple ways, the search of other 
importance lectins is the object of this work. When we plan to investigate the relationship between the lectin existence and the nature of immunomodulatory activity of a different protein extracted from a group of Moroccan plants selected in the previous study (Daoudi et al., 2012).

The identification of lectin activity is evaluated by the erythro-agglutination method, the partial characterization of the lectin is determined by the inhibition of the erythro-agglutination compared to the Concanavalin-A effects; Concanavalin-A is lectin obtained from Canavalia enseiformis specific to $\alpha$-D-mannosyl and $\alpha$-D-glucosyl terminal residues (Kennedy et al., 1995).

\section{Materials and Methods}

\subsection{Chemicals}

The chemicals and reagents were purchased from Sigma-Aldrich Co., St. Louis,MO, USA and were of analytical grade. Phosphate buffered saline (PBS) was used at concentration of $15 \mathrm{mM}(\mathrm{pH}$ 7.4). Concanavaline-A (Con-A, $1 \mathrm{mg} / \mathrm{mL}$ ) was prepared in PBS and used at a final concentration of $7 \mu \mathrm{g} / \mathrm{mL}$. The following sugars were used at concentration of $0.2 \mathrm{M}$ in PBS; and were purchased from Sigma-Aldrich Co., St. Louis,MO, USA: D-glucose (D-glc), D-melezitose (D-mel), D-mannitol (D-mat), D-lactose (D-lac), D-sorbitol (D-sor), D-sucrose (D-suc), D-galactose (D-gal), D-cellobiose (D-cel), D-arabinose (D-ara), N-acétyl-glucosamine (D-N-acglc), D-maltose (D-mal), D-mannose (D-man).

\subsection{Plant Materials}

\subsubsection{Choice of Plant}

The plants tested were chosen based on our previous publications on assessments of a group of plants used in Moroccan traditional medicine for their immunomodulatory effects (Daoudi et al., 2012). The tested plants were classified into three groups; the first group includes Lepidium sativum L, Datura stramonium L and Delphinium staphysagria L. with an immuunostimulating effects. The second group showed an immunosuppressive effects and includes Citrullus colocynthis L and Piper cubeba L. and the third group which has no immunomodulating effects on the proliferation of splenocytes induced by mitogenic factor Concanavalin-A, this group includes Elettaria cardamomum L, Marrubium vulgare L, Ammi visnaga $\mathrm{L}$, Aristolochia longa $\mathrm{L}$.

\subsubsection{Preparation of Plant Protein Extract}

The protein extract (PE) of each plant was prepared according to the previous procedures published by Daoudi et al. (2012). Briefly, the PE is prepared from the total extract after precipitation by the addition of cold ammonium sulfate (44\%) at $4{ }^{\circ} \mathrm{C}$ (England \& Seifter, 1990). In this study, we have used the PE at the $100 \mu \mathrm{g} / \mathrm{mL}$ of PBS as final concentration for all plants tested. This concentration was determined using method reported by Lowry's et al. (1951), using bovine serum albumin (BSA) as a standard.

\subsection{Cell Materials}

\subsubsection{Preparation of Erythrocyte Suspension}

The erythrocytes materials were isolated from the rabbit animals (Papillon species unvaccinated of 2-2.5 Kg). The animals were housed and maintained with a standard diet in an air conditioned and clean room. The blood was collected from the neck of the animals after scarification into heparinized hemolytic tubes. The erythrocytes cells are obtained from three successive washes of the blood with the physiological saline $(0.9 \% \mathrm{NaCl})$ by successive centrifugation ( $3 \mathrm{~min}$ at $2000 \mathrm{rpm}$ ). The erythrocyte suspension is adjusted to $2 \%(\mathrm{v} / \mathrm{v})$ in $0.9 \% \mathrm{NaCl}$ and stored at $4{ }^{\circ} \mathrm{C}$, until further uses.

\subsubsection{Erythro-Agglutination Assay}

Erythro-agglutination assay was performed using modified method of Kabat and Mayer (1961) and Fik et al. (2000). Assays were performed in 96 wells plate. Erythroagglutination was monitored macroscopically and confirmed microscopically.

Three groups of experiments were performed, in the first group (PE group), $25 \mu \mathrm{L}$ of the erythrocyte suspension was incubated with $25 \mu \mathrm{L}$ of PE at (100 $\mu \mathrm{g} / \mathrm{mL}$ PBS) and $50 \mu \mathrm{L}$ of PBS (total volume $100 \mu \mathrm{L}$ ). In the second group (negative control group), $25 \mu \mathrm{L}$ of the erythrocyte suspension was incubated with $75 \mu \mathrm{L}$ of PBS and in the third group (positive control group), $25 \mu \mathrm{L}$ of the erythrocyte suspension was incubated with $50 \mu \mathrm{L}$ of PBS and $25 \mu \mathrm{L}$ of Con-A at concentration $7 \mu \mathrm{g} / \mathrm{mL}$. In all groups, the wells were carried out in triplicate and incubated for a period of $30 \mathrm{~min}$ at $37^{\circ} \mathrm{C}$.

\subsubsection{Erythro-Agglutination-Inhibition Assay}

The assay was performed according to the protocol of Oda and Minami (1986) by introducing into each well a 
$25 \mu \mathrm{L}$ of PE of each plant, $50 \mu \mathrm{L}$ of the sugar suspension at $0.2 \mathrm{M}$ in PBS. The sugars tested as inhibitors are: D-glucose, D-melezitose, D-mannitol, D-lactose, D-sorbitol, D-sucrose, D-galactose, D-cellobiose, D-arabinose, $\mathrm{N}$-acetylglucosamine, D-maltose, and D-mannose. After $30 \mathrm{~min}$ at room temperature, $25 \mu \mathrm{L}$ of the $2 \%$ erythrocyte suspension were added to each well and the plates were then incubated for $30 \mathrm{~min}$ at room temperature.

The control experiments for inhibition of the erythro-agglutination were carried as follows: positive control with Con-A and its sugars inhibition (D-mannose and D-glucose) (Goldstein \& Poretz, 1986); negative control with cells alone, without sugars and without PE.

\section{Results}

\subsection{Identification of the Lectin Activity of the Immunomodulating Protein Plant Extracts}

In the present study, nine immunomodulatory protein plants extracts were tested, to assess the property of its content lectin, using the erythroagglutinating activity of the rabbit erythrocytes. The erythroagglutinating activity was evaluated macroscopically by a cell ring formed at the bottom of the wells comparing with the erythro-agglutining activity of Con-A as positive control.

The microscopic observation was used for further confirmation. The result obtained is summarized in Table 1, from which three groups of plant activities could recognize:

Group 1: This group showed erythroagglutinating activity and includes PE of L. sativum L, D. stramonium L, D. staphysagria $\mathrm{L}$ and P. cubeba $\mathrm{L}$.

Group 2: All the plant extracts of this group showed no erythroagglutinating effects on erythrocytes, this group includes $E$. cardamomum $\mathrm{L}, A$. visnaga $\mathrm{L}, A$. longa $\mathrm{L}$ and $C$. colocynthis $\mathrm{L}$.

Group 3: This group includes only $M$. vulgare L, and showed hemolytic effect rather than erythroagglutination.

\subsection{Relationship Between Immunomodulatory Activity and Lectin Properties}

The result obtained is summarized in Table 1, from which three groups of plant activities could recognized and also the relation between the immunomodulatory activity of the PE and lectin content. The degree of erythro-agglutination is determined by the minimum concentration of lectin inducing erythro-agglutination.

Group 1: This group showed erythroagglutinating activity and includes PE of L. sativum L, D. stramonium L, and D. staphysagria $\mathrm{L}$.

Group 2: All the plants of this group showed neither immune nor erythro-agglutinating effects on the erythrocytes, this group includes E. cardamomum L, M. vulgare L, A. visnaga L, A. longa L.

Group 3: Plants of this group are immunosuppressive with or without erythroagglutinating, and this $P$. cubeba $\mathrm{L}$ and C. colocynthis $\mathrm{L}$.

This result showed no relationship between the immunomodulating effects of the protein extract and its content of lectin, which explained that lectins do not always have immunostimmulants effects, as they may be immune compromising lectins. On the other hand non-lectin protein substances may act through their immunomodulating effects. The result showed also that the degree of erythro-agglutinating activity varied among the concentration of the lectin in the protein extracts.

\subsection{Erythro-Agglutination Inhibition Assay}

The determination of the partial nature of lectins is based on the inhibition of erythro-sugar agglutination test (Lima et al., 2005; Eghianruwa et al., 2011). Sugars that inhibited erythro-lectin erythro-agglutination constitute the carbohydrate portion of the lectin. This inhibitory effect of the sugar can be attributed to their ability to compete for binding sites on the lectin molecule, which can interfere with the attachment of the lectin to sugar units on the surface of the erythrocytes.

The positive and negative controls should be prompted systematically performed. The results presented in Table 2 , shows a comparison of sugar inhibitions of erythro-agglutiation of different lectins previously identified in Figure 1. With the sugars tested at concentration of $0.2 \mathrm{M}$, we found that erythro-agglutination of $L$. sativum is not inhibited by the tested sugars (D-glc; D-mel; D-mat; D-lac; D-sor; D-suc; D-gal; D-cel; D-ara; D-N-acglc; D-mal; D-man). On other hand, D. stramonium is only inhibited by D-N-acglc, while the eryhtro-agglutination caused by $P$. cubeba is inhibited by sugars such as: D-mel; D-mat; D-lac; D-suc; D-gal; D-cel; D-mal; D-man. The lectin Con-A tested as control is rather inhibited by their references by which sugars are (D-glc and D-man). 
Table 1. Evaluation of the relationship between the lectins activity and the immunomodulating protein extracted

\begin{tabular}{|c|c|c|c|c|}
\hline & & Degre & glutination & {$[\mathrm{PE}]$} \\
\hline Negative control & & Cells alone & - & \\
\hline \multirow{9}{*}{$\begin{array}{c}\text { Protein extract } \\
\text { tested }\end{array}$} & \multirow{4}{*}{$\begin{array}{c}\text { immunostimulator } \\
\text { ativity }\end{array}$} & Cells + Lepidium sativum $L$, & +++ & $25 \mu \mathrm{g} / \mathrm{mL}$ \\
\hline & & Cells + Datura stramonium $L$, & +++ & $25 \mu \mathrm{g} / \mathrm{mL}$ \\
\hline & & Cells + Delphinium staphysagria $\mathrm{L}$, & + & $100 \mu \mathrm{g} / \mathrm{mL}$ \\
\hline & & Cells + Elettaria cardamomum L, & - & \\
\hline & \multirow{3}{*}{ no immuno activity } & Cells + Marrubium vulgare L, & $\mathrm{H}$ & \\
\hline & & Cells + Ammi visnaga $\mathrm{L}$ & - & \\
\hline & & Cells + Aristolochia longa $\mathrm{L}$ & - & \\
\hline & immunosuppressive & Cells + Piper cubeba & ++ & $50 \mu \mathrm{g} / \mathrm{mL}$ \\
\hline & activity & Cells + Citrullus colocynthis L, & - & \\
\hline Positive control & & Cells + Con-A, & + & $100 \mu \mathrm{g} / \mathrm{mL}$ \\
\hline
\end{tabular}

(+): Agglutination activity.

$(-)$ : No agglutination activity.

(H): Hemolysis.

[PE]: Minimum concentration of erythro-agglutination observed.

Table 2. Evaluation of the sugar inhibition from the lectins activity

\begin{tabular}{|c|c|c|c|c|c|c|c|c|c|c|c|c|c|}
\hline & & D-glc & D-mel & D-mat & D-lac & D-sor & D-suc & D-gal & D-cel & D-ara & D-N-acglc & D-man & D-mal \\
\hline 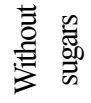 & $\begin{array}{c}\text { Negative } \\
\text { control }\end{array}$ & - & - & - & - & - & - & - & - & - & - & - & - \\
\hline \multirow{5}{*}{ 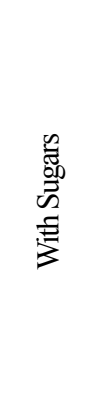 } & Cells + Lesa & + & + & + & + & + & + & + & + & + & + & + & + \\
\hline & Cells $+p i c u$ & + & - & - & - & + & - & - & - & + & + & - & - \\
\hline & Cells + Dest & + & + & + & + & + & + & + & + & + & + & + & + \\
\hline & Cells + Dast & + & + & + & + & + & + & + & + & + & - & + & + \\
\hline & $\begin{array}{c}\text { Cells + } \\
\text { Con-A } \\
\text { (Positive } \\
\text { control) }\end{array}$ & - & & & & & & & & & & - & \\
\hline
\end{tabular}

Sugars tested as inhibitors of erythro-aglutination are: D-glucose (D-glc), D-melezitose (D-mel), D-mannitol (D-mat), D-lactose (D-lac), D-sorbitol (D-sor), D-sucrose (D-suc), D-galactose (D-gal), D-cellobiose (D-cel), D-arabinose (D-ara), N-acétyl-glucosamine (D-N-acglc), D-maltose (D-mal), D-mannose (D-man).

Erythroa-gglutinating plants tested were: Lepidium sativum (Le sa), Piper cubeba (Pi cu), Delphinium staphysagria (De st), Datura stramonium (Da st).

Negative control: (Cells alone), Positive control: (Cells + Con-A).

(+): Degree of agglutination activity; (-): Degree of inhibition agglutination activity. 


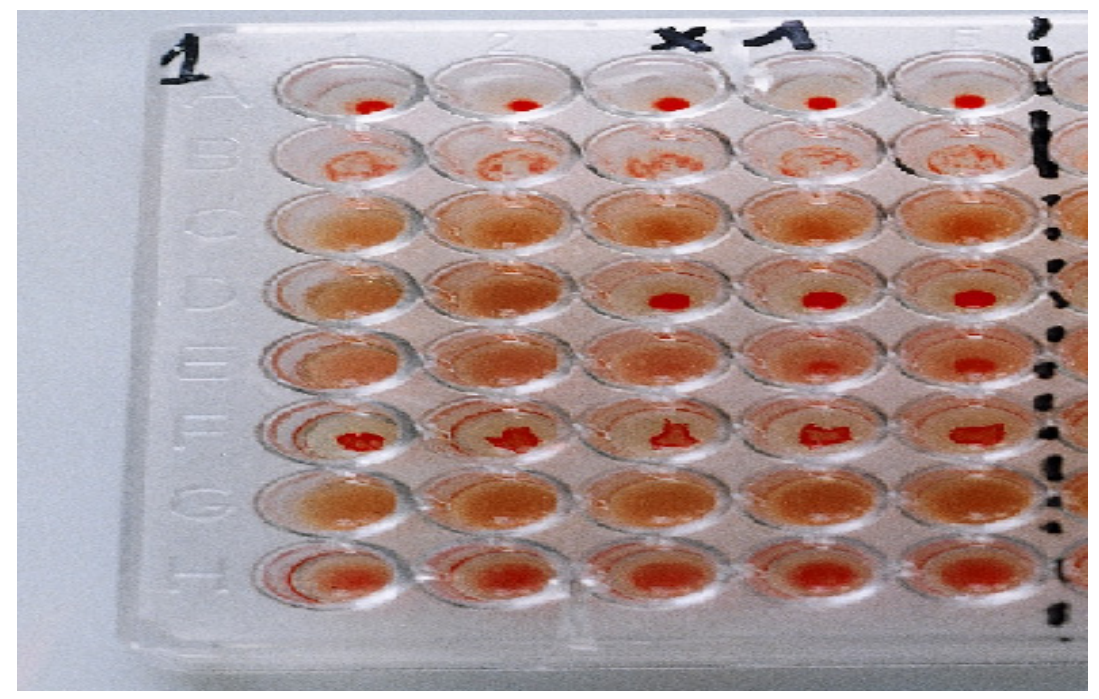

Figure 1. Example of macroscopic observation of erythro-agglutination induced by protein extracted of plants The results are revealed by the presence or absence of a ring in the wells of the plate. (Wells: $1 \rightarrow 5$ ): Direction of decreasing concentration of the protein extract tested.

A (1-5) Cells alone (-); inhibition of erythro-agglutination;

$\mathrm{H}$ (1-5) Cells with Con-A (++); Presence of erythro-agglutination.

F (1-5) Cells with Datura stramonium (+++); Presence of high erythro-agglutination.

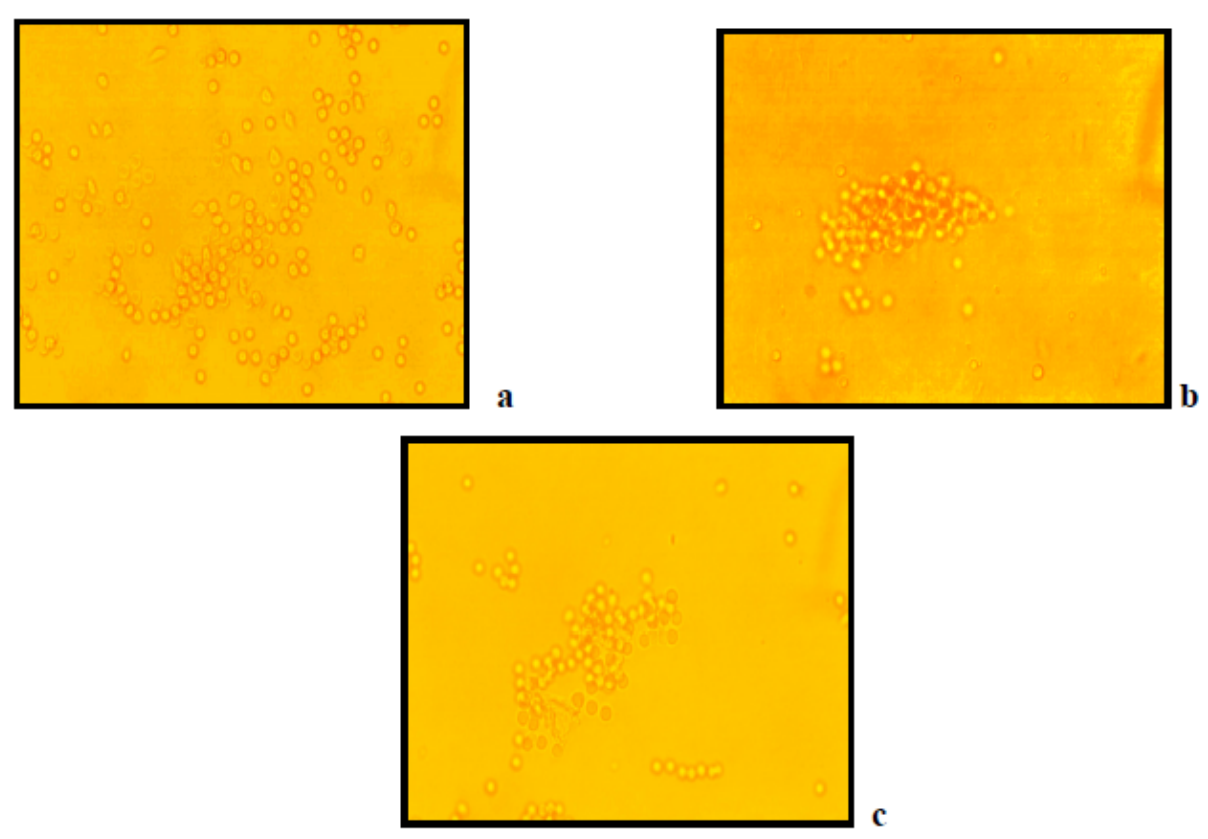

Figure 2. Example of microscopic confirmation of erythro-agglutination induced by protein extracted of plants (X 100)

a. Cell only (negative control); the cell are dispersed.

b. Cell with Datura stramonium extracts; the cell are grouped.

c. Cell with Con-A (positive control); the cell are more grouped.

\section{Discussion}

According to the results of this study, the protein plant extracts tested were classified into three groups by 
interested relationship between immunomodulating and the presence of lectin in the protein extract. The erythro-agglutination test is a simple and a practical method for the detection of the lectins activity compared to the Conc-A; e.g. lectin from Canavalia ensiformis (Einhoff \& Rüdiger, 1986).

The results show that some lectins may be acting on the immunostimulating of immune responses and this is clear for $D$. stramonium, $L$. sativum and $D$. staphysagria with a very high degree of erythro-agglutination for $D$. stramonium $L$. This is explained by the biological activity of lectins in particular, through physicochemical characteristics of lectins (molecular weight, $\mathrm{pH}$, presence of divalent cations activations (Edelman et al., 1972; Van damme et al., 1987), through type of lectin in particular, the biochemical structure of lectin (rearrangement amino acids constituting or the conformation structural of lectin) (Strosberg et al., 1986; Chrispeels \& Raikhel, 1991), or even the saccharide specificity lectins, which is defined in terms to minimum concentration of monosaccharides needed to inhibit the agglutination cells (Goldstein \& Hayes, 1978).

In the previous study, we have showed that the seeds of D. stramonium contain a lectin (DSA), responsible for the proliferation of human lymphocytes (McCurrach \& Kilpatrick, 1988) and inhibited just by the NAcetyl-D-glucosamine (Desai et al., 1981; Crowley et al., 1984; Kennedy et al., 1995). The seeds of L. sativum contain a glycoprotein type lectin not inhibited by the monosaccharides (Ziska et al., 1982).

The inhibition of erythro-agglutination could mean that the determinants of sugar membranes of the erythrocytes are the binding sites for the tested sugars occupying the sites of carbohydrate components of the lectin. The presence of multiple of erythro-agglutination inhibition for $P$. cubeba $\mathrm{L}$, could be explained by multiple of varieties such as carbohydrate fraction of lectin which can interact with the various sugars tested, or it is possible that the binding sites are flexible on the size and shape of the remaining sugars (Elmer-Rico et al., 2005). Lectin from $P$. cubeba $\mathrm{L}$, evokes us to consider what could be used in the phytotherapy in camparison with the lectins from bacteria and fungus that cause immunosuppression for its opportunistic infection and immunopathological complications during its immunosuppressive effects (Beuth et al., 1987; van de Veerdonk et al., 2008; Fontaine et al., 2011).

In addition, the absence of erythro-agglutination results could be explained by the absence of structural features necessary for inhibition of sugar. Osawa (1966) described the structural characteristics which should be present in lectins with sugar inhibiting activity (Elmer-Rico et al., 2005).

The other protein extract devoid from lectin could be immunomodulating, this may be through non lectin pathway or through the lectin content that can act on other cells and does not agglutinate erythrocytes, and/or according to the concentration of lectin content. The negative result, cannot confirm the absence of lectins, since the activity can exist when lectins are measured in different conditions, or when the extracted were incubated with other cell types such as lymphocytes or sperms, since three iso-agglutinins extracted from tubers of Colocasia esulenta agglutinate human sperm with erythro-agglutination activity (Promplook \& Chulavatnatol, 1986).

\section{Conclusion}

The use of bio-active compounds for modulation of immune system must be vigilant following the sensitivity of this system and the mode of action of these substances. The plant protein extract can be immune in nature and lectin induce allergic hypersensitivity or opportunistic of infections and in cancer.

This study is a platform to place a link between the immunomodulatory effect and lectin activity. Several lectins exert the immunomodulatory activities that are initiated by their interaction with the glycan fragments on the surface of immune cells, and induce a potent immune responses as immunostimulatory, immune depression (opportunistic infections), or an immuno compromising as an excessiveness of the immune reaction (allergy), but they can also be harmful by disrupting the biological or structural functioning of other cells such as sperm or erythrocytes.

\section{References}

Beuth, J., Ko, H. L., Schroten, H., Sölter, J., Uhlenbrock, G., \& Pulverer, G. (1987). Lectin mediated adhesion of Streptococcus pneumoniae and its specific inhibition in vitro and in vivo. Zentralbl Bakteriol, Mikrobiol Hyg A, 265(1-2), 160-168.

Boyd, W. C., \& Shapleigh, E. (1954). Specific precipitation activity of plant agglutinins (lectins). Science, 119, 419. http://dx.doi.org/10.1126/science.119.3091.419

Chrispeels, M. J., \& Raikhel, N. V. (1991). Lectins, lectin genes, and their role in plant defense. The Plant Cell, 3, 1-9. http://dx.doi.org/10.2307/3869195 
Crowley, J. F., Goldstein, I. J., Arnarp, J., \& Lönngren, J. (1984). Carbohydrate binding studies on the lectin from Datura stramonium seeds. Archives of biochemistry and biophysics, 231(2), 524-533. http://dx.doi.org/10.1016/0003-9861(84)90417-X

Daoudi, A., Aarab, L., \& Abdel-Sattar, E. (2012). Screening of immunomodulatory activity of total and protein extracts of some Moroccan medicinal plants. Toxicology and industrial health, 29(3), 245-253. http://dx.doi.org/10.1177/0748233711430972

De Melo, C. M., Melo, H., Correia, M. T., Coelho, L. C., da Silva, M. B., \& Pereira, V. R. (2011). Mitogenic response and cytokine production induced by cramoll 1,4 lectin in splenocytes of inoculated mice. Scandinavian journal of immunology, 73(2), 112-121. http://dx.doi.org/10.1111/j.1365-3083.2010.02490.x

De Oliveira, S. F., das Neves, S. P., de Melo, C. M., Teixeira, E. H., de Sousa, C. B., Arruda, F. V., .. Porto, A. L. (2011). Immunostimulatory activity of ConBr: a focus on splenocyte proliferation and proliferative cytokine secretion. Cell and tissue research, 346, 237-344. http://dx.doi.org/10.1007/s00441-011-1239-x

Desai, N. N., Allen, A. K., \& Neuberger, A. (1981). Some properties of the lectin (Datura stramonium (thon-apple) and the nature of its glycoprotein linkages. Biochemical Journal, 211(1), 273-276.

Edelman, G. M., Cunningham, B. A., Reeke, G. N., Becker, J. W., Waxdal, M. J., \& Wang, J. L. (1972). The covalent and three-dimensional structure of Concanavalin A. Proceedings of the National Academy of Sciences of the United States of America, 62, 2580-2585. http://dx.doi.org/10.1073/pnas.69.9.2580

Eghianruwa, Q., Odekanyin, O., \& Kuku, A. (2011). Physicochemical properties and acute toxicity studies of a lectin from the saline extract of the fruiting bodies of the shiitake mushroom, Lentinula edodes (Berk). International Journal Biochemistry and Molecular Biology, 2(4), 309-317.

Einhoff, W., \& Rüdiger, H. (1986). Isolation of the Canavalia ensiformis seed alpha-mannosidase by chromatography on concanavalin A, the lectin from the same plant, without involving its sugar binding site. Biological chemistry Hoppe-Seyler, 367(4), 313-320. http://dx.doi.org/10.1515/bchm3.1986.367.1.313

Elmer-Rico, E., Mojica, Florinia, E., \& Merca. (2005). Isolation and partial characterization of a lectin from the Internal Organs of the Sea Cucumber (Holothuria scabra Jaeger). International Journal of Zoological Research, 1, 59-65. http://dx.doi.org/10.3923/ijzr.2005.59.65

England, S., \& Seifter, S. (1990). Precipitation techniques. Methods in Enzymology, 182, 285-300. http://dx.doi.org/10.1016/0076-6879(90)82024-V

Fik, E., Dalgalarrondo, M., Haertlé, T., \& Gozdzicka-Jozefiak, A. (2000). Comparative biochimical analysis of lectin and nuclease from Chelidonium majus L. Acta Biochimica Polonica, 47(2), 413-420.

Fontaine, T., Delangle, A., Simenel, C., Coddeville, B., van Vliet, S. J., van Kooyk, Y., ... Latge, J. P. (2011). Galactosaminogalactan, a new immunosuppressive polysaccharide of Aspergillus fumigates. PLoS pathogens, 7(11), 1-13. http://dx.doi.org/10.1371/journal.ppat.1002372

Frost, R. G., Reitherman, W., Miller, A. L., \& O'Brien, J. S. (1975). Purification of Ulex europeus hemagglutinin I $\begin{array}{llrr}\text { by affinity chromatography. Analytical biochemistry, } & 69(1), \quad 170-179 .\end{array}$ http://dx.doi.org/10.1016/0003-2697(75)90578-3

Goldstein, I. J., \& Hayes, C. E. (1978). The lectins: carbohydrate-binding proteins of plants and animals. Advances in Carbohydrate Chemistry \& Biochemistry, $35, \quad$ 127-340. http://dx.doi.org/10.1016/S0065-2318(08)60220-6

Goldstein, I. J., Hughes, R. C., Monsigny, M., Osawa, T., \& Sharon, N. (1980). What should be called a lectin?. Nature, 285(5760), 66. http://dx.doi.org/10.1038/285066b0

Guillot, J., Guerry, M., Konska, G., Caldefie-Chezet, F., De Latour, M., \& Penault-Llorca, F. (2004). Modification des glycoconjugués au cours du processus de cancérisation : cas des carcinomes mammaires. Bulletin du Cancer, 91(2), 141-158.

Hirabayashi, J. (2004). Lectin-based structural glycomics: glycoproteomics and glycan profiling. Glycoconjugate Journal, 21(1-2), 35-40. http://dx.doi.org/10.1023/B:GLYC.0000043745.18988.al

Kabat, E. A., \& Mayer, M. M. (1961). Experimental Immunochemistry (2nd ed.), In C. Charles Thomas. (pp. 149-153). Springfield, IL.

Kennedy, J. F., Palva, P. M. G., Correia, M. T. S., Cavalcanti, M. S. M., \& Coelho, L. C. B. B. (1995). Lectins, versatile proteins of recognition: a review. Carbohydrate Polymers- Journal, 26(3), 219-230. 
http://dx.doi.org/10.1016/0144-8617(94)00091-7

Khan, F., Ahmad, A., \& Khan, M. I. (2007). Purification and characterization of a lectin from endophytic fungus Fusarium solani having complex sugar specificity. Archives Biochemistry Biophysics, 457, 243-251. http://dx.doi.org/10.1016/j.abb.2006.10.019

Lee, J. Y., Kim, J. Y., Lee, Y. G., Byeon, S. E., Kim, B. H., Rhee, M. H., ... Cho, J. Y. (2007). In vitro immunoregulatory effects of Korean mistletoe lectin on functional activation of monocytic and macrophage-like cells. Biological Pharmaceutical Bulletin, 30(11), 2043-2051. http://dx.doi.org/10.1248/bpb.30.2043

Lima, M. E., Carneiro, M. E., Nascimento, A. E., Grangeiro, T. B., Holanda, M. L., Amorim, R. C., \& Benevides, N. M. (2005). Purification of a Lectin from the Marine Red Alga Gracilaria cornea and Its Effects on the Cattle Tick Boophilus microplus (Acari: Ixodidae). Journal of Agricultural Food Chemistry, 53(16), 6414-6419. http://dx.doi.org/10.1021/jf0509660

Liu, B., Bian, H. J., \& Bao J. K. (2010). Plant lectins: potential antineoplastic drugs from bench to clinic. Cancer Letters- Journal, 287(1), 1-12. http://dx.doi.org/10.1016/j.canlet.2009.05.013

Lowry, O. H., Rosebrough, N. J., Farr, A. L., \& Randall, R. J. (1951). Protein measurement with the Folin phenol reagent. Journal Biological Chemistry, 193, 265-275.

McCurrach, P. M., \& Kilpatrick, D. C. (1988). Datura lectin is both an anti-mitogen and a co-mitogen acting synergistically with phorbol ester. Scandinavian Journal Immunology, 27(1), 31-34. http://dx.doi.org/10.1111/j.1365-3083.1988.tb02320.x

Meite, A., Kouame, K. G., \& Séraphin, K. C. (2006). Lectins: antinutritional substances? Médecine. Nutrition, 42(4), 179-187.

Meite, A., Kouame, K. G., \& Offoumou, A. M. (2008). Evaluation de l'activité hémagglutinante des lectines des graines de trois espèces de Cucurbitaceae couramment consommées en Côte d'Ivoire. Sciences \& Nature, 5(2), 199-204.

Melo, C. M. L., Paim, B. A., Zecchin, K. G., Morari, J., Chiarrati, M. R., Correia, M. T. S., ... Paiva, P. M. G. (2010). Cramoll 1,4 lectin increases ROS production, calcium levels and cytokine expression in treated spleen cells of rats. Molecular and Cellular Biochemistry, 342, 163-169. http://dx.doi.org/10.1007/s11010-010-0480-z

Oda, Y., \& Minami, K. (1986). Isolation and characterization of a lectin from tulip bulbs, Tulipa gesneriana. European Journal of Biochemistry, 159(2), 239-245. http://dx.doi.org/10.1111/j.1432-1033.1986.tb09859.x

Osawa, T. (1966). Inhibition tests of plant agglutinins from Laburnum alpinum and Cytisus sessifolius with various sugars and sugar derivatives. Indication of the type of linkage in certain disaccharides. Biochem. Biophys. Acta, 115, 507-510. http://dx.doi.org/10.1016/0304-4165(66)90455-7

Peumans, W. J., \& Van Damme, E. J. M. (1995). Lectins as plant defense proteins. Plant Physiology, 109(2), 347-352. http://dx.doi.org/10.1104/pp.109.2.347

Peumans, W. J., \& Van Damme, E. J. M. (1998). Plants lectins: specific tools for theidentification, isolation and characterization of O-linked glycans. Critical Reviews in Biochemistry and Molecular Biology, 33(3), 209-258.

Promplook, P., \& Chulavatnatol, M. (1986). Three sperm-agglutinating isoagglutinins from tubers of Taro (Colocasia esculenta). in Lectins: Biology, Biochemistry, Clinical Biochemistry, Vol 5, (In T. C. Bog-Hansen \& E. Van Driessche (Eds.) (pp. 109-116). New York: Walter de Gruyter, Berlin.

Qu, X. M., Zhang, C. F., Komano, H., \& Natori, S. (1986). Purification of a lectin from the hemolymph of Chinese oak silk moth (Antheraea pernyi) pupae. Journal Biochemistry, 101, 545-551. http://dx.doi.org/10.1093/jb/101.3.545

Ringnér, M., Valkonen, K. H., Wadström, T. (1994). Binding of vitronectin and plasminogen to Helicobacter $\begin{array}{lllll}\text { pylori. FEMS Immunology \& Medical } & \text { Microbiology, 9, }\end{array}$ http://dx.doi.org/10.1111/j.1574-695X.1994.tb00470.x

Rubinstein, N., Ilarregui, J. M., Toscano, M. A., \& Rabinovich, G. A. (2004). The role of galectins in the initiation, amplification and resolution of the inflammatory response. Tissue Antigens Journal, 64(1), 1-12.

Ryder, S. D., Smith, J. A., \& Rhodes, J. M. (1992). Peanut lectin: a mitogen for normal human colonic epithelium 
and human HT29 colorectal cancer cells. Journal of National Cancer Institute, 84(18), 1410-1416. http://dx.doi.org/10.1093/jnci/84.18.1410

Strosberg, A. D., Buffard, D., Lauwereys, M., \& Foriers, A. (1986). Legume lectins: a large family of homologous proteins. In I. E. Liener, N. Sharon, I. J. Goldstein (Eds.), The Lectins: Properties, Functions, and Applications in Biology and Medicine (pp. 249-264). New York: Academic Press.

Van Damme, E. J. M., Allen, A. K., \& Peumans, W. J. (1987). Isolation and characterization of a lectin with exclusive specificity towards mannose from snowdrop Galanthus nivalis bulbs. FEBS Letters- Journal, 215(1), 140-144. http://dx.doi.org/10.1016/0014-5793(87)80129-1

Van de Veerdonk, F. L., Kullberg, B. J., van der Meer, J. W. M., Gow, N. A. R., \& Netea, M. G. (2008). Host microbe interactions: innate pattern recognition of fungal pathogens. Current Opinion in Microbiology, 11(4), 305-312. http://dx.doi.org/10.1016/j.mib.2008.06.002

Wang, H. X., Liu, W. K., Ng, T. B., Ooi, V. E., \& Chang, S. T. (1996). The immunomodulatory and antitumor activities of lectins from the mushroom Tricholoma mongolicum. Immunopharmacology, 31(2-3), $205-211$. http://dx.doi.org/10.1016/0162-3109(95)00049-6

Ziska, P., Kindt, A., \& Franz, H. (1982). Isolation and characterization of a lectin from garden cress (Lepidium sativum), Acta Histochemica, 71(1), 29-33.

Zwierzina, H., Bergmann, L., Fiebig, H., Aamdal, S., Schöffski, P., Witthohn, K., \& Lentzen, H. (2011). The preclinical and clinical activity of aviscumine: A potential anticancer drug. European Journal of Cancer, 47(10), 1450-1457. http://dx.doi.org/10.1016/j.ejca.2011.02.022

\section{Copyrights}

Copyright for this article is retained by the author(s), with first publication rights granted to the journal.

This is an open-access article distributed under the terms and conditions of the Creative Commons Attribution license (http://creativecommons.org/licenses/by/3.0/). 